medRxiv preprint doi: https://doi.org/10.1101/2021.10.13.21264946; this version posted December 13, 2021. The copyright holder for this preprint (which was not certified by peer review) is the author/funder, who has granted medRxiv a license to display the preprint in perpetuity.

All rights reserved. No reuse allowed without permission.

\title{
Clinical observation of high-flow nasal cannula with non-rebreather mask use on severe or critically ill COVID-19 diabetic patients
}

1 AFM Tareq Bhuiyan, Department of Anesthesia and ICU, 250 Bedded General Hospital, Chattogram, 4000, Bangladesh. E-mail: tbhuiyan83@gmail.com

${ }^{2}$ Sudipta Deb Nath, Department of Genetic Engineering and Biotechnology, University of Dhaka, Dhaka, 1000, Bangladesh. E-mail: sudipto.sb45@gmail.com

${ }^{3}$ Md Jakir Hossain, Pancreatic Research Group, South Western Sydney Clinical School, Faculty of Medicine and Health, UNSW Sydney, Sydney 2052, Australia. E-mail: jakir.hossain@unsw.edu.au

4 Shuva Das, Department of Microbiology, Chittagong Medical College, Chattogram, 4203, Bangladesh. E-mail: shuvadas47cmchgeb@gmail.com

${ }^{5}$ Moumita Das, Department of Anesthesia and ICU, 250 Bedded General Hospital, Chattogram, 4000, Bangladesh. Email: moumita.das.2822@gmail.com
${ }^{6}$ Moinul Ahsan, Department of Anesthesia and ICU, 250 Bedded General Hospital, Chattogram, 4000, Bangladesh. E- mail: dr.moinul78@gmail.com

7 Md. Iftekher-E-Alam Ziad, Department of Anesthesia and ICU, 250 Bedded General Hospital, Chattogram, 4000, Bangladesh. E-mail: iftekherziad@gmail.com

8 Fahmida Khatun Padma, Department of Anesthesia and ICU, Chittagong Medical College, Chattogram, 4203, Bangladesh. E-mail: padmafahmida4@gmail.com

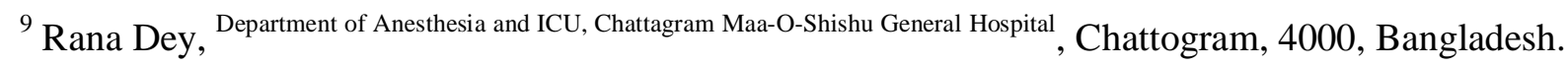
E-mail: ranaprata415@gmail.com

10 AKM Shamsul Alam, ICU, Parkview Hospital, Chattogram, 4203, Bangladesh. E-mail: alamakms@yahoo.com 
medRxiv preprint doi: https://doi.org/10.1101/2021.10.13.21264946; this version posted December 13, 2021. The copyright holder for this preprint (which was not certified by peer review) is the author/funder, who has granted medRxiv a license to display the preprint in perpetuity. All rights reserved. No reuse allowed without permission.

11 Farial Hoque Zehan, Department of Anesthesia and ICU, 250 Bedded General Hospital, Chattogram, 4000, Bangladesh. E-mail: fhzehan@gmail.com

${ }^{*}$ Ayan Saha, Department of Genetic Engineering and Biotechnology, East West University, Dhaka, 1212, Bangladesh. Email: ayan.saha.bd@gmail.com

*Correspondence: Dr. Ayan Saha, Assistant Professor, Department of Genetic Engineering and Biotechnology, East West University, Dhaka, 1212, Bangladesh, Email: ayan.saha.bd@gmail.com, Phone: +880 1999-061196

\section{Highlights:}

1. Elderly diabetic patients required both HFNC and NRM to increase oxygen saturation.

2. Hypertension may be a factor for diabetic patients with COVID-19 requiring HFNC and NRM together.

3. 'HFNC + NRM' - combination therapy might be needed when blood glucose levels rise. 
medRxiv preprint doi: https://doi.org/10.1101/2021.10.13.21264946; this version posted December 13, 2021. The copyright holder for this preprint (which was not certified by peer review) is the author/funder, who has granted medRxiv a license to display the preprint in perpetuity. All rights reserved. No reuse allowed without permission.

\section{Abstract}

Background and aims: Prevalence of diabetes is a vital factor in COVID-19's clinical prognosis. This study aimed to investigate and compare the efficacy of High-flow Nasal Cannula (HFNC) with/without non-rebreather mask (NRM) use on critical COVID-19 patients with/without diabetes.

Methods: For analysis and comparison, epidemiological, biochemical, and clinical data were collected from 240 HFNC $( \pm$ NRM) treated severe and critical COVID-19 patients (diabetic = 136; non-diabetic $=104)$ admitted into ICUs of five hospitals in Chattogram, Bangladesh.

Results: $59.1 \%$ of patients with fever had diabetes $(\mathrm{p}=0.012)$. ICU stay was longer for diabetic patients $(9.06 \pm 5.70)$ than non-diabetic patients $(7.41 \pm 5.11)(\mathrm{p}=0.020)$. Majority of the hypertensive patients were diabetic $(68.3 \% ; \mathrm{p}<0.001)$. Majority of diabetic patients $(70.4 \% ; \mathrm{p}<0.005)$ had elevated creatinine levels. Partial pressure of oxygen (mmHg) after HFNC (only) administration was significantly $(\mathrm{p}=0.031)$ higher in non-diabetic patients $(69.30 \pm 23.56)$ than in diabetic patients (61.50 \pm 14.49$)$. Diabetic $(62.64 \pm 13.05)$ and non-diabetic patients $(59.40 \pm 13.22)$ had almost similar partial pressure of oxygen ( $\mathrm{mmHg}$ ) from HFNC with NRM. Patients with elevated RBS required NRM with HFNC five times (AOR=5.1, 1.2-20.8) higher than others. Besides age, and hypertension were significantly associated with the HFNC+NRM treated diabetic patients. Factors those affected the HFNC only treated patients were fever and impaired glucose tolerance.

Conclusions: The results of this study imply that oxygen supply with HFNC and NRM may be beneficial for the elderly/hypertensive diabetic patients with COVID-19 associated AHRF; and that increased blood glucose level could be a determinant for the need of HFNC + NRM treatment.

Keywords: HFNC; NRM; ICU; Diabetes; COVID-19. 
medRxiv preprint doi: https://doi.org/10.1101/2021.10.13.21264946; this version posted December 13, 2021. The copyright holder for this

\section{Introduction}

Coronavirus Disease 2019 (COVID-19) is a multisystem illness that majorly affects the respiratory tract; induced by a newer variant of the severe acute respiratory syndrome-related Coronavirus (SARS-CoV-2) [1]. The breakout of the then novel virus was detected in Wuhan, China by the end of December 2019 and in a very short span of time, the SARS-CoV-2 being highly contagious was able to rapidly spread between populations. The rather fast global spread of the disease and its severe clinical outcomes prompted the World Health Organization to proclaim it a pandemic on March 11, 2020 [2, 3].

During the outbreak, case-control studies on COVID-19 found that comorbid conditions like diabetes mellitus might predict COVID-19 advancement in patients [3]. Although the evidence is limited, recent research has suggested that diabetes and high blood sugar levels can operate as predictor variables in COVID-19-related disease burden; firstly, as because diabetic patients have a weakened immune system, they take longer to recover from viral infections, and secondly, since the virus may survive in a high-glucose condition. These denominators put people with diabetes in a susceptible position in terms of COVID-19 fatalities [4-6]. Furthermore, several COVID-19 related long-term sequelae have been reported in current research [7, 8], necessitating comprehensive inquiry and evaluation to confirm the evidence in depth.

Bangladesh ranks eighth among the world's most populous countries, with almost 161 million people [9]. To date, more than 0.7 million infected cases have been reported in Bangladesh, while the lethalities have reached a count of more than 12 thousand (https://iedcr.gov.bd/). Diabetes, among other chronic disease states, seems to be on the upswing in Bangladesh at a rapid pace, with 8.4 million instances in adults, according to data from the International Diabetes Federation (IDF) [10]. A number of studies reported strong correlation between diabetes and COVID-19 [11, 12].

The high number of severe and critical COVID-19 cases has imposed an unprecedented strain on the healthcare system, emphasizing the need for rapid and effective COVID-19 treatment with 
medRxiv preprint doi: https://doi.org/10.1101/2021.10.13.21264946; this version posted December 13, 2021. The copyright holder for this

complication management. Several investigations have found that a severe or critical progression of COVID-19 causes acute hypoxemic respiratory failure (AHRF), which necessitates a high fractional concentration of inspired oxygen $\left(\mathrm{FiO}_{2}\right)$ and noninvasive ventilation (NIV) techniques such as a face mask, a non-rebreather mask (NRM) etc. [13-16]. HFNC, on the other hand, tends to be more successful than others because it can reach $100 \%$ humidification at $37^{\circ} \mathrm{C}$ and has a positive end-expiratory pressure (PEEP) effect while patients breathe with the mouth closed [17, 18].

The relation between COVID-19 and diabetes, as well as the condition's long-term effects on people, is still being researched and investigated. This study focuses on seeing how HFNC with NRM compares to mechanical ventilation (MV) in diabetic COVID-19 patients hospitalized in different ICUs in Bangladesh. Our goal was to shed light on this technique's usefulness in severe or critical instances where MV facilities are limited. The findings of this study can assist specialist doctors and the whole healthcare system of our country in expanding the range of treatment options available to individuals suffering from life-threatening COVID-19 consequences.

\section{Materials and Methods}

\subsection{Sample size and data collection}

A cross-sectional observational study was carried out with a sample of 240 COVID-19 patients who required medical attention in various medical facilities and were verified positive by Real-time Reverse-transcriptase Polymerase Chain Reaction (rRT-PCR) analysis.

Patients (diabetic or non-diabetic) with a requirement of HFNC with or without NRM were deemed candidates. As the primary sources of data, a pertinent questionnaire and medical history were used. All retrospective data gathered via telephone interviews were manually entered into an online format. All data entered on the questionnaire that matched the participants' responses were doublechecked before being posted and the recordings were stored.

\subsection{Ethical approval}


medRxiv preprint doi: https://doi.org/10.1101/2021.10.13.21264946; this version posted December 13, 2021. The copyright holder for this

This research and its protocol were approved by the 250 Bedded Chattogram General Hospital's Institutional Review Board (Approval No.: 1724).

\subsection{Inclusion and exclusion criteria}

COVID-19 subjects with $6.5 \%$ glycated haemoglobin (HbA1c) content, who had recently demonstrated any validated biochemical examination of diabetes mellitus were included in the diabetes cohort. Uncontrolled hyperglycemia was classified into two or more blood glucose level examinations that yielded a result more than $11.1 \mathrm{mmol} / \mathrm{l}$, regardless of blood sugar levels.

Patients having dyspnea, i.e. a respiratory rate of $\geq 30$ beats per minute in rest and sustained $\mathrm{SpO}_{2}$ less than $90 \%$ after receiving 15 liters per minute of oxygen were deemed candidates for HFNC. Besides, those who failed to maintain desired oxygen saturation $\left(\mathrm{SpO}_{2}>90 \%\right)$ after high flow were also given a face mask containing NRM and HFNC. They were enlisted in the 'severe' category. Those with respiratory failure, sepsis, or shock, which necessitated MV, as well as those with multiple organ failures requiring ICU support, were placed in the 'critical' category. Patients who required MV or NIV from the start of their ICU stay, as well as those who refused to participate in the research, were excluded. The Berlin definition was used to specify acute respiratory distress syndrome (ARDS), and the Sepsis-3 criteria were utilized to define shock [19, 20].

\subsection{Study sites}

The research was carried out in five hospitals: the 250 bedded Chattogram General Hospital, Chittagong Medical College Hospital, Chattagram Maa-Shishu O General Hospital, and Parkview Hospital. These hospitals have dedicated general as well as intensive care units for the treatment and management of COVID-19 patients.

The cases' epidemiological and demographic data were obtained by assigned investigators from the patients' treatment records and interviews with the accompanying personnel. The study took place between April 15, 2021, and June 14, 2021.

\section{5. rRT-PCR test}


medRxiv preprint doi: https://doi.org/10.1101/2021.10.13.21264946; this version posted December 13, 2021. The copyright holder for this

Throat swabs, nasopharyngeal swabs, and bronchial aspirates were obtained from patients and placed in a collection tube with a viral transport medium before being sent to the research laboratories. The SARS-CoV-2 RNA extraction for COVID-19 was carried out in the Molecular Biology laboratory of the Microbiology department of Chittagong Medical College in accordance with WHO guidelines [21].

\subsection{Statistical analysis}

To check possible correlations between categorical variables, Pearson's Chi-Square $(\chi 2)$ (where $<20 \%$ of cells had expected count less than 5) and Fisher's Exact (where $\geq 20 \%$ of cells had expected count less than 5) evaluation methods were used. Categorical and continuous variables were tested for associations by applying Independent-Samples T-Test (95\% confidence interval) and 'means' with 'standard deviations' were compared. $P$ values less than 0.05 were considered statistically significant. $P$ value of "Equal variance not assumed" was considered in case of categorical and continuous variable correlation. Factors that had significant differences when correlating with diabetic/non-diabetic group were further analyzed by dividing into two groups HFNC only and HFNC + NRM treated patients. Then the statistically significant factors were analyzed against HFNC only and HFNC + NRM by Simple bivariate logistic regression and multiple bivariate logistic regression to find the significant factors, crude odds ratio (COR), adjusted odds ratio (AOR), and their ranges at $95 \%$ confidence interval. Omnibus tests of model coefficients' $P$ values less than 0.05 and Hosmer and Lemeshow Goodness of Fit test's $P$ values greater than 0.05 were considered significant to test if the regression model had been fit for the data. Specificity and sensitivity of the data were also tested during regression analysis. All data analysis tests were performed in IBM SPSS version-25.

\section{Results:}

\subsection{Basic socio-demographic characteristics and Investigation result of the patients}


medRxiv preprint doi: https://doi.org/10.1101/2021.10.13.21264946; this version posted December 13, 2021. The copyright holder for this

Table 1 illustrates the basic demographic characteristics of HFNC treated patients. We found that the prevalence of diabetes among female patients (64.6\%), those $\geq 50$ years of age $(64.1 \%)$, urban residents (57.9\%), previously smokers $(56.0 \%)$, and those who never smoked (57.6\%) within the study sample (Table 1). Age was significantly related to diabetes mellitus ( $\mathrm{p}<0.001)$. In this data, $20.8 \%(50 / 240)$ patients did not have any comorbidities $(\mathrm{p}<0.001)$. Among the hypertensive and IHD patients, $31.7 \%$ and $29.8 \%$ were non-diabetic, respectively $(\mathrm{p}<0.001 \& \mathrm{p}=0.037)$ (Table 1). Persistence of fever had a significant association with diabetes mellitus $(\mathrm{p}=0.012)$, and $59.1 \%$ of the feverish patients had diabetes. Other than fever, cough $(72.5 \% ; 174 / 240)$ and breathlessness $(67.5 \% ; 162 / 240)$ were common symptoms. Among 240 patients who comprised the study sample, $47.1 \%$ (113) patients were given HFNC and NRM oxygenation simultaneously, and 52.9\% (127) patients were treated with HFNC only (Table 1). Among the 126 patients who died during the study period, $56.3 \%$ were diabetic. For diabetic cases, the duration (in days) between the first onset of COVID-19 associated symptoms and death was higher $(17.48 \pm 7.15)(\mathrm{p}=0.006)$. Additionally, for diabetic patients the stay in the ICU was longer $(9.06 \pm 5.70)$ as compared to the non-diabetic patients $(7.41 \pm 5.11)(\mathrm{p}=0.020)($ Table 1$)$.

Data obtained from each patient's investigation report has been included in Table 1. Random blood sugar (RBS) and serum creatinine levels were significantly related to diabetes mellitus $(\mathrm{p}=0.039 \&$ $\mathrm{p}=0.005)$. Amongst those with high creatinine level, $70.4 \%$ were diabetic, and $29.6 \%$ were nondiabetic (Table 1).

\subsection{Immediate complications of the patients}

Supplementary Figure 1 (a) and (b) representing the complications of HFNC, show that nonvisible nasal bleeding followed by nasal obstruction by clotted blood was the most observable complication. We found that in the study sample, non-diabetic patients $(76 / 104 ; 73.1 \%)$ suffered from HFNC complications more than diabetic patients $(96 / 136 ; 70.6 \%)$ (Supplementary Figure 1). In this study, $38.2 \%$ of the diabetic patients and $42.3 \%$ of the non-diabetic patients had the 
medRxiv preprint doi: https://doi.org/10.1101/2021.10.13.21264946; this version posted December 13, 2021. The copyright holder for this

aforementioned complications before their death. Other complications of HFNC were headache $(59 / 240 ; 24.6 \%)$, discomfort $(71 / 240 ; 29.6 \%)$, and frequent displacement of the nasal cannula (89/240; 37.1\%) (Supplementary Figure 1). In addition, complaints relating to the irritation in the nostrils were also reported by the patients, which is considered as an indication of discomfort in the current survey.

\subsection{Impact of HFNC and other treatments}

The impact of HFNC and NRM on ICU admitted COVID-19 induced AHRF patients is illustrated in Table 2. The partial pressure of oxygen $(\mathrm{mmHg})$ after the administration of HFNC (only) was significantly $(\mathrm{p}=0.031)$ higher for the non-diabetic patients $(69.30 \pm 23.56)$ than those with diabetes $(61.50 \pm 14.49)($ Table 2$)$.

Table 3 describes the impact of HFNC (with/without NRM) on diabetic and non-diabetic patients with COVID-19 induced AHRF. Among the patients who were treated with both HFNC and NRM, the prevalence of AHRF was higher for those aged $\geq 50$ years with diabetes $(67.4 \%)(\mathrm{p}<0.001)$. Elderly diabetic patients needed HFNC concomitant with NRM (Table 3). Most of the patients who did not have any comorbidity $(62.0 \% ; 31 / 50)$ were managed with HFNC only $(\mathrm{p}<0.001)$. Higher proportions of diabetic patients having hypertension had to be treated with both HFNC (singularly) (70.1\%) and HFNC combined with NRM (66.7\%) than the non-diabetic hypertensive cases (Table 3). A total of $58.4 \%$ of the patients treated with only HFNC were diabetic and had elevated body temperature $(\mathrm{p}=0.034)$. Besides, most of the patients who needed both HFNC and NRM had raised RBS $(73.8 \% ; p=0.001)$ and creatinine levels $(75.7 \% ; p=0.009)($ Table 3).

Figure 1 (a) and (b) show the treatment protocols alongside HFNC (with/without NRM) for the diabetic and non-diabetic patients, respectively. The protocol included antivirals, antibiotics, steroids, low molecular weight heparin, interleukin-6 inhibitor (Tocilizumab), and convalescent plasma therapy (Figure 1). Among patients with diabetes, the survival ratio after only HFNC was higher for those who were given oral (100.0\%) antiviral drugs than those administered in 
medRxiv preprint doi: https://doi.org/10.1101/2021.10.13.21264946; this version posted December 13, 2021. The copyright holder for this

intravenous (IV) (35.3\%) form. But the response rate of IV antivirals (58.7\%) increased when NRM was also used for treating them. On the contrary, the survival rate was high after using IV antivirals beside HFNC concomitant with (50.0\%)/without (75.0\%) NRM amongst the patients not having diabetes (Figure 1). The response rate of IV antibiotics to survival/death was not significantly different after HFNC administration with/without NRM for patients not/having diabetes. When plasma therapy was given with both HFNC and NRM, the survival rate was significantly high among non-diabetic patients with COVID-19 induced AHRF (100.0\%). Another observation was a high survival rate among the diabetic patients after giving dexamethasone with HFNC + NRM (62.7\%) (Figure 1). The majority of non-diabetic patients $(62.5 \%)$ having administered both HFNC and NRM survived when they got tocilizumab treatment. Though the survival percentages among non-diabetic patients after HFNC (with/without NRM) and heparin were almost similar, a twice-daily dose of heparin with HFNC + NRM could save $63.6 \%$ of the diabetic patients (Figure 1).

\subsection{Factors associated with HFNC with/without NRM}

Non-diabetic patients who were managed with only HFNC were 6.5 (1.3-33.1) times less feverish than diabetic patients. The chance of having IGT was about twelve times (AOR=12,1.1-129.8) high for the diabetic COVID-19 patients who were also given only HFNC to maintain their oxygenation (Table 4).

The chance of being aged at least 50 years was almost six $(\mathrm{AOR}=6.2,1.1-31.2)$ times higher among diabetic HFNC + NRM treated patients. Non-diabetic patients (HFNC + NRM treated) were more likely to have hypertension than diabetic ones. Moreover, among HFNC + NRM treated patients, diabetic patients were five times $(A O R=5.1,1.2-20.8)$ more likely to have increased blood glucose levels (Table 4).

\section{Discussion:}


medRxiv preprint doi: https://doi.org/10.1101/2021.10.13.21264946; this version posted December 13, 2021. The copyright holder for this

Because a previous study recommended the usage of HFNC for minimizing invasive/mechanical ventilation use [22], in this study, the clinical effect of HFNC as a mode of providing supplemental oxygenation to COVID-19 diabetic patients was observed to analyze whether the use of this mechanism is efficient enough to be reiterated on a large scale to reduce the burden of MV support in the context of Bangladesh's COVID-19 landscape. When HFNC failed to maintain the optimum oxygenation with at least $92 \%$ of $\mathrm{SpO}_{2}, \mathrm{NRM}$ was also added to the ICU admitted patients. We also tried to find the success rate of using NRM concomitant with HFNC to the COVID-19 induced AHRF diabetic patients.

In this data, 136 among 240 HFNC treated AHRF patients had diabetes as comorbidity, which aligns with the statement by a study in China, which stated that diabetes mellitus is a commonly observed comorbidity in severe COVID-19 cases [23]. Diabetes among elderly patients was considered a risk factor for the severe prognosis of COVID-19 [11, 24]. Similar to a study in Bangladesh, the proportion of diabetic COVID-19 patients was significantly higher among those aged $\geq 50$ years [12]. The findings of this survey showed that a great proportion (almost 6 times) of the elderly diabetic patients needed both HFNC and NRM to maintain their oxygenation because they could not maintain the optimum oxygen level with HFNC only.

Analogous to previous studies, we found a higher mortality rate among COVID-19 patients with type-2 diabetes compared with the non-diabetic patients, establishing diabetes as a risk factor for increased mortality $[23,25,26]$. As per the current study's findings, face masks with non-rebreather reservoir bags were given together with HFNC to 113 patients, and among them, $58.4 \%$ were diabetic. After using nasal cannula only, non-diabetic patients showed more improvement of $\mathrm{PaO}_{2}$ than the diabetic ones. So, to maintain oxygenation of the severely/critically ill COVID-19 diabetic patients, NRM was also needed along with HFNC.

Saha et al. asserted the high prevalence of hypertension among the diabetic COVID-19 patients, and it was an important factor in the progression of COVID-19 for severe/critical patients [12]. In 
medRxiv preprint doi: https://doi.org/10.1101/2021.10.13.21264946; this version posted December 13, 2021. The copyright holder for this

this study, it was observed that hypertensive diabetic COVID-19 patients required NRM along with HFNC to maintain the oxygen saturation. Besides, a significant difference in the presence of heart disease among diabetic and non-diabetic patients was also found in this current study. High prevalence of fever was found among the AHRF patients with diabetes in this study and only HFNC treated diabetic patients being 6.5 times more feverish might prove that fever was common among diabetic patients. As all the patients in this study were admitted to the ICU due to hypoxemic respiratory failure following COVID-19, the duration of ICU stay of the diabetic and non-diabetic patients was also observed. This study found a noticeable difference between them. Diabetic patients had to stay in the ICU for a longer period than those who did not have diabetes.

Increased blood glucose level is established as a determinant in the pathogenesis of the infectious disease, like the SARS-CoV-2 virus, and can make the diabetic patients immunocompromised, leading to their critical conditions after SARS-CoV-2 infection $[27,28]$. This data supporting these studies proved that most of the severely/critically ill patients faced a rise in blood sugar, and among them, more than $60 \%$ were previously diabetic. Moreover, among diabetic patients only HFNC treated ones showed a high odds ratio of having IGT and HFNC + NRM treated ones showed of having increased blood glucose level. This data might prove that those who had increased blood glucose level rather of having IGT needed both HFNC and NRM to maintain their oxygen level.

In a study in China, it was stated that COVID-19 patients gradually develop kidney dysfunctions/acute kidney injury (AKI) as SARS-CoV-2 uses ACE2 (angiotensin-converting enzyme II) as a cell entry receptor [29]. A PubMed database indicates that ACE2 RNA expressions in gastrointestinal organs (small intestine, duodenum) and urinary organs (kidney) are much higher (nearly 100-fold) than that in lungs [30]. Compliant with these data, this current study noticed that increased serum creatinine level was found significantly among critically ill COVID-19 patients, and most of them did not have a previous history of kidney disease. Moreover, creatinine rise was high for those who were diabetic, and this indicates that elevation of creatinine level might be a determining factor of severity during SARS-CoV-2 infection for diabetic patients. As the severity 
medRxiv preprint doi: https://doi.org/10.1101/2021.10.13.21264946; this version posted December 13, 2021. The copyright holder for this

of the disease for ICU admitted COVID-19 patients might increase because of diabetes and lately developed kidney dysfunction, HFNC and NRM both were needed to support most of the patients with raised sugar and creatinine levels.

Non-visible nasal bleeding along with mucosal obstruction was common for both diabetic and nondiabetic patients. So, to prevent this, liquid paraffin and normal saline were used. As this was a locally practiced procedure, more research is needed to establish the process for averting these complications. In a study, it was established that glucocorticoids can induce varying degrees of diabetes and this was similar to our data when patients were given steroids [31]. So, insulin was administered to all who were previously diabetic/ had been taking oral hypoglycemic drugs or insulin (switched from oral to injectable form)/ developed diabetes as a side effect of steroids. Dexamethasone with HFNC and NRM showed a good survival ratio for the diabetic patients, but convalescent plasma therapy worked effectively (with HFNC and NRM) for the non-diabetic patients showing a survival rate of $100.0 \%$.

\section{Conclusion:}

This study was conducted for analyzing the clinical outcomes of HFNC with/without a NRM on severely ill COVID-19 diabetic patients. As per the findings, the majority of the elderly diabetic and hypertensive diabetic patients needed both HFNC and NRM to sustain their oxygenation. Furthermore, increased blood sugar might prove that it may be a determining factor for the need of HFN + NRM for COVID-19 induced AHRF diabetic patients. As it is a multicentric prospective study, the findings of this study are representative of the situation of most hospitals in Bangladesh. As HFNC with/without NRM as per this study, was found to have association with a significant clinical improvement in severe case of COVID-19 in both diabetic and non-diabetic cases, the burden on MV and clinical demand of MV in constrained clinical settings can be to some extent reduced by considering HFNC with/without NRM and other therapeutics as an efficient candidate for supplemental oxygenation. 
medRxiv preprint doi: https://doi.org/10.1101/2021.10.13.21264946; this version posted December 13, 2021. The copyright holder for this

Abbreviation: HFNC; High Flow Nasal Cannula, NRM; Face Mask with Non-Rebreathing Reservoir Bag/Non-Rebreather Mask, COVID-19; Coronavirus Disease 2019, ICU; Intensive Care Unit, RBS; Random Blood Sugar, SARS-CoV-2; Severe Acute Respiratory Syndrome related Coronavirus, AHRF; Acute Hypoxemic Respiratory Failure, $\mathrm{FiO}_{2}$; Fractional Concentration of Inspired Oxygen, NIV; Non-Invasive Ventilation, MV; Mechanical ventilation, $\mathrm{SpO}_{2}$; Percent Saturation of Oxygen, IHD; Ischemic Heart Disease, rRT-PCR; Real Time Reverse TranscriptasePolymerase Chain Reaction, WHO; World Health Organization, WBC; White Blood Cell, $\mathrm{PaO}_{2}$; Partial Pressure of Oxygen, SD; Standard Deviation

\section{Declarations:}

Funding: This study was self-funded by authors.

Conflicts of interest: The authors have no conflicts of interest to declare that are relevant to the content of this article.

Authors' Contributions: AFM Tareq Bhuiyan: Design, clinical studies, data acquisition; Sudipta Deb Nath: Data acquisition, data analysis, manuscript preparation; Md Jakir Hossain: Concepts, data analysis, manuscript review; Shuva Das: Experimental studies, manuscript preparation; Moumita Das: Concepts, clinical studies; Moinul Ahsan: Statistical analysis; Md. Iftekher-E-Alam Ziad: Clinical studies; Fahmida Khatun Padma: Clinical studies; Rana Dey: Clinical studies; AKM Shamsul Alam: Manuscript editing; Farial Hoque Zehan: Clinical studies; Ayan Saha: Design, Manuscript preparation

Acknowledgements: Authors would like to thank the authorities of 250 bedded Chattogram General Hospital, Chittagong Medical College Hospital, Chattagram Maa-Shishu O General Hospital, Parkview Hospital, and Surgiscope Hospital Ltd. 
medRxiv preprint doi: https://doi.org/10.1101/2021.10.13.21264946; this version posted December 13, 2021. The copyright holder for this

\section{References:}

[1] Jin Y, Yang H, Ji W, Wu W, Chen S, Zhang W, et al. Virology, epidemiology, pathogenesis, and control of covid-19. Viruses. 2020;12.

[2] Hussain A, Bhowmik B, do Vale Moreira NC. COVID-19 and diabetes: Knowledge in progress. Diabetes Res Clin Pract. 2020;162:108142-.

[3] Alkundi A, Mahmoud I, Musa A, Naveed S, Alshawwaf M. Clinical characteristics and outcomes of COVID-19 hospitalized patients with diabetes in the United Kingdom: A retrospective single centre study. Diabetes Res Clin Pract. 2020;165.

[4] Fadini GP, Morieri ML, Longato E, Avogaro A. Prevalence and impact of diabetes among people infected with SARS-CoV-2. J Endocrinol Invest. 2020;43:867-9.

[5] Guo W, Li M, Dong Y, Zhou H, Zhang Z, Tian C, et al. Diabetes is a risk factor for the progression and prognosis of COVID-19. Diabetes/metabolism research and reviews. 2020:e3319.

[6] Muniyappa R, Gubbi S. COVID-19 pandemic, coronaviruses, and diabetes mellitus. American Journal of Physiology-Endocrinology and Metabolism. 2020;318:E736-E41.

[7] Carfi A, Bernabei R, Landi F, Group ftGAC-P-ACS. Persistent symptoms in patients after acute covid-19. Jama. 2020;324:603-5.

[8] Jiang DH, McCoy RG. Planning for the post-covid syndrome: How payers can mitigate long-term complications of the pandemic. Journal of general internal medicine. 2020;35:3036-9.

[9] DESA. World population prospects 2019: Highlights. . United Nations Department for Economic and Social Affairs; 2019.

[10] Saeedi P, Petersohn I, Salpea P, Malanda B, Karuranga S, Unwin N, et al. Global and regional diabetes prevalence estimates for 2019 and projections for 2030 and 2045: Results 
medRxiv preprint doi: https://doi.org/10.1101/2021.10.13.21264946; this version posted December 13, 2021. The copyright holder for this

from the International Diabetes Federation Diabetes Atlas, 9(th) edition. Diabetes Res Clin Pract. 2019;157:107843.

[11] Akter F, Mannan A, Mehedi HMH, Rob MA, Ahmed S, Salauddin A, et al. Clinical characteristics and short term outcomes after recovery from covid-19 in patients with and without diabetes in Bangladesh. Diabetes Metab Syndr. 2020;14:2031-8.

[12] Saha A, Ahsan MM, Quader MT, Naher S, Akter F, Mehedi HMH, et al. Clinical characteristics and outcomes of COVID-19 infected diabetic patients admitted in ICUs of the southern region of Bangladesh. Diabetes Metab Syndr. 2021;15:229-35.

[13] Antonelli M, Conti G, Rocco M, Bufi M, De Blasi RA, Vivino G, et al. A comparison of noninvasive positive-pressure ventilation and conventional mechanical ventilation in patients with acute respiratory failure. The New England journal of medicine. 1998;339:429-35.

[14] Carrillo A, Gonzalez-Diaz G, Ferrer M, Martinez-Quintana ME, Lopez-Martinez A, Llamas $\mathrm{N}$, et al. Non-invasive ventilation in community-acquired pneumonia and severe acute respiratory failure. Intensive care medicine. 2012;38:458-66.

[15] Delclaux C, L'Her E, Alberti C, Mancebo J, Abroug F, Conti G, et al. Treatment of acute hypoxemic nonhypercapnic respiratory insufficiency with continuous positive airway pressure delivered by a face mask: A randomized controlled trial. Jama. 2000;284:2352-60.

[16] Hilbert G, Gruson D, Vargas F, Valentino R, Chene G, Boiron JM, et al. Noninvasive continuous positive airway pressure in neutropenic patients with acute respiratory failure requiring intensive care unit admission. Critical care medicine. 2000;28:3185-90.

[17] Sztrymf B, Messika J, Bertrand F, Hurel D, Leon R, Dreyfuss D, et al. Beneficial effects of humidified high flow nasal oxygen in critical care patients: a prospective pilot study. Intensive care medicine. 2011;37:1780-6.

[18] Roca O, Riera J, Torres F, Masclans JR. High-flow oxygen therapy in acute respiratory failure. Respiratory care. 2010;55:408-13. 
medRxiv preprint doi: https://doi.org/10.1101/2021.10.13.21264946; this version posted December 13, 2021. The copyright holder for this

[19] Ranieri VM, Rubenfeld GD, Thompson BT, Ferguson ND, Caldwell E, Fan E, et al. Acute respiratory distress syndrome: the Berlin Definition. Jama. 2012;307:2526-33.

[20] Singer M, Deutschman CS, Seymour CW, Shankar-Hari M, Annane D, Bauer M, et al. The third international consensus definitions for sepsis and septic shock (sepsis-3). Jama. 2016;315:801-10.

[21] Rudra S, Das S, Hoque M, Kalam A, Rahman M. Delay of detection of covid-19 patients in Bangladesh, an application to cox proportional hazard model. Journal of Antivirals \& Antiretrovirals. 2021;13:218.

[22] Matthay MA, Aldrich JM, Gotts JE. Treatment for severe acute respiratory distress syndrome from COVID-19. The Lancet Respiratory medicine. 2020;8:433-4.

[23] Zhou F, Yu T, Du R, Fan G, Liu Y, Liu Z, et al. Clinical course and risk factors for mortality of adult inpatients with COVID-19 in Wuhan, China: a retrospective cohort study. The Lancet. 2020;395:1054-62.

[24] Zhou P, Yang X-L, Wang X-G, Hu B, Zhang L, Zhang W, et al. A pneumonia outbreak associated with a new coronavirus of probable bat origin. Nature. 2020;579:270-3.

[25] Acharya D, Lee K, Lee DS, Lee YS, Moon SS. Mortality rate and predictors of mortality in hospitalized covid-19 patients with diabetes. Healthcare (Basel, Switzerland). 2020;8.

[26] Shenoy A, Ismaily M, Bajaj M. Diabetes and covid-19: a global health challenge. BMJ Open Diabetes Research \&amp; Care. 2020;8:e001450.

[27] Casqueiro J, Casqueiro J, Alves C. Infections in patients with diabetes mellitus: A review of pathogenesis. Indian J Endocrinol Metab. 2012;16 Suppl 1:S27-S36.

[28] Wu F, Zhao S, Yu B, Chen Y-M, Wang W, Song Z-G, et al. A new coronavirus associated with human respiratory disease in China. Nature. 2020;579:265-9.

[29] Li Z, Wu M, Yao J, Guo J, Liao X, Song S, et al. Caution on Kidney Dysfunctions of COVID-19 Patients. medRxiv. 2020:2020.02.08.20021212. 
medRxiv preprint doi: https://doi.org/10.1101/2021.10.13.21264946; this version posted December 13, 2021. The copyright holder for this preprint (which was not certified by peer review) is the author/funder, who has granted medRxiv a license to display the preprint in perpetuity. All rights reserved. No reuse allowed without permission.

[30] Fagerberg L, Hallström BM, Oksvold P, Kampf C, Djureinovic D, Odeberg J, et al. Analysis of the human tissue-specific expression by genome-wide integration of transcriptomics and antibody-based proteomics. Molecular \& cellular proteomics : MCP. 2014;13:397-406.

[31] Yasuda K, Hines E, 3rd, Kitabchi AE. Hypercortisolism and insulin resistance: comparative effects of prednisone, hydrocortisone, and dexamethasone on insulin binding of human erythrocytes. The Journal of clinical endocrinology and metabolism. 1982;55:910-5. 
medRxiv preprint doi: https://doi.org/10.1101/2021.10.13.21264946; this version posted December 13, 2021. The copyright holder for this preprint (which was not certified by peer review) is the author/funder, who has granted medRxiv a license to display the preprint in perpetuity.

All rights reserved. No reuse allowed without permission.

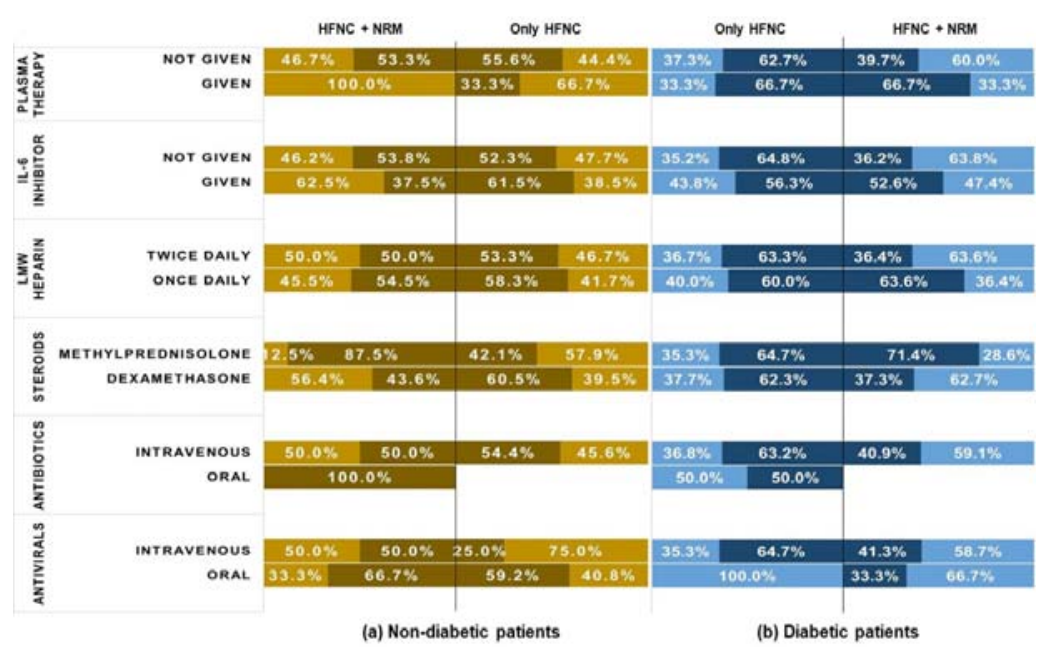

Figure 1: Brown (a) and blue (b) represent the treatments for non-diabetic and diabetic patients, respectively. Light and dark shades of (a) and (b) indicate survival and death rate after the treatments. One side of the black divider of each color denotes the percentage of patients treated with HFNC only, while another side signifies HFNC + NRM treated patients' percentage. $\mathrm{HFNC}=$ High Flow Nasal Cannula, NRM= Non-Rebreather Mask, IL-6 inhibitor= Interleukin-6 inhibitor, LMW Heparin= Low Molecular Weight Heparin 
Table 1: Basic Demographic Characteristics and Investigations of patients treated with HFNC.

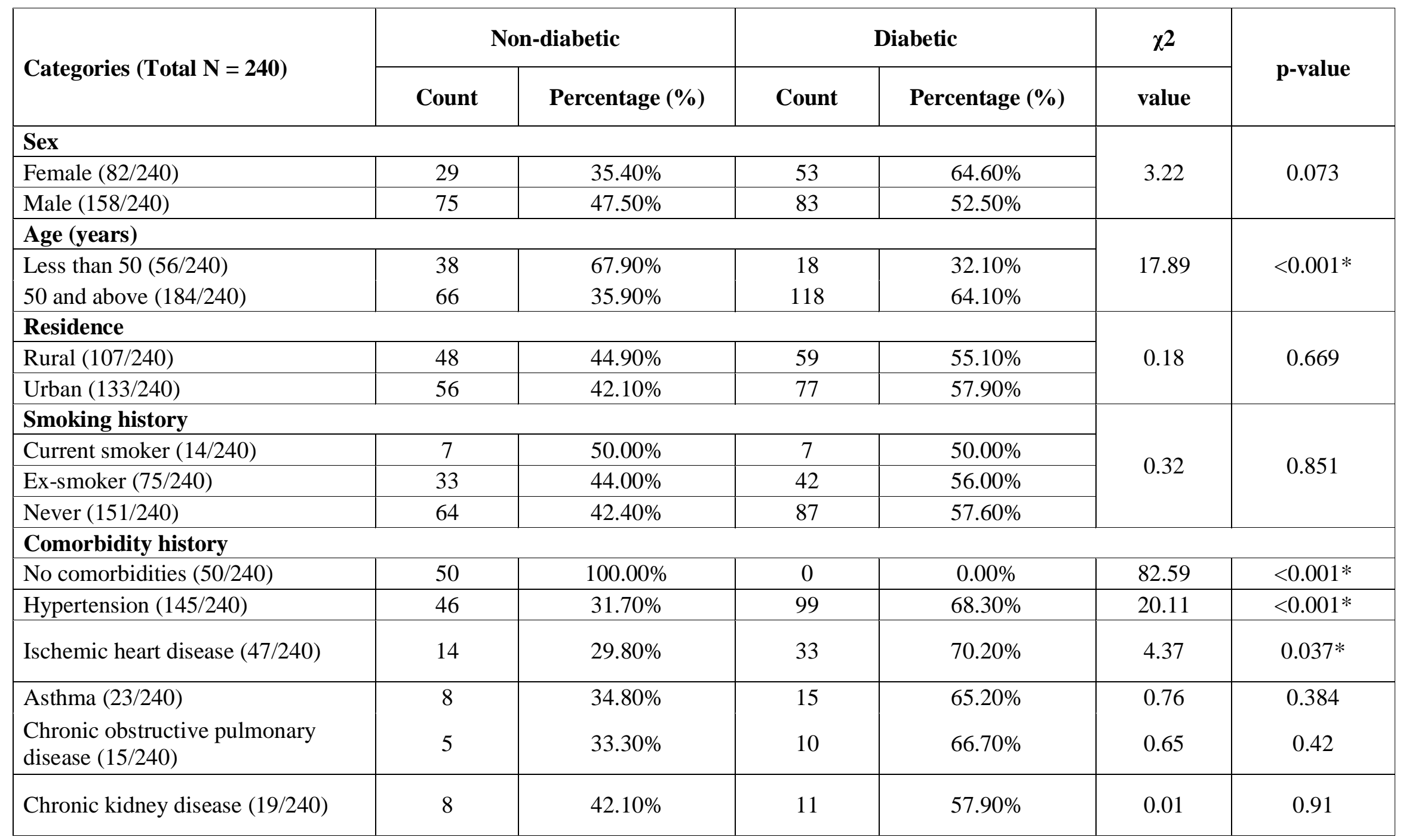




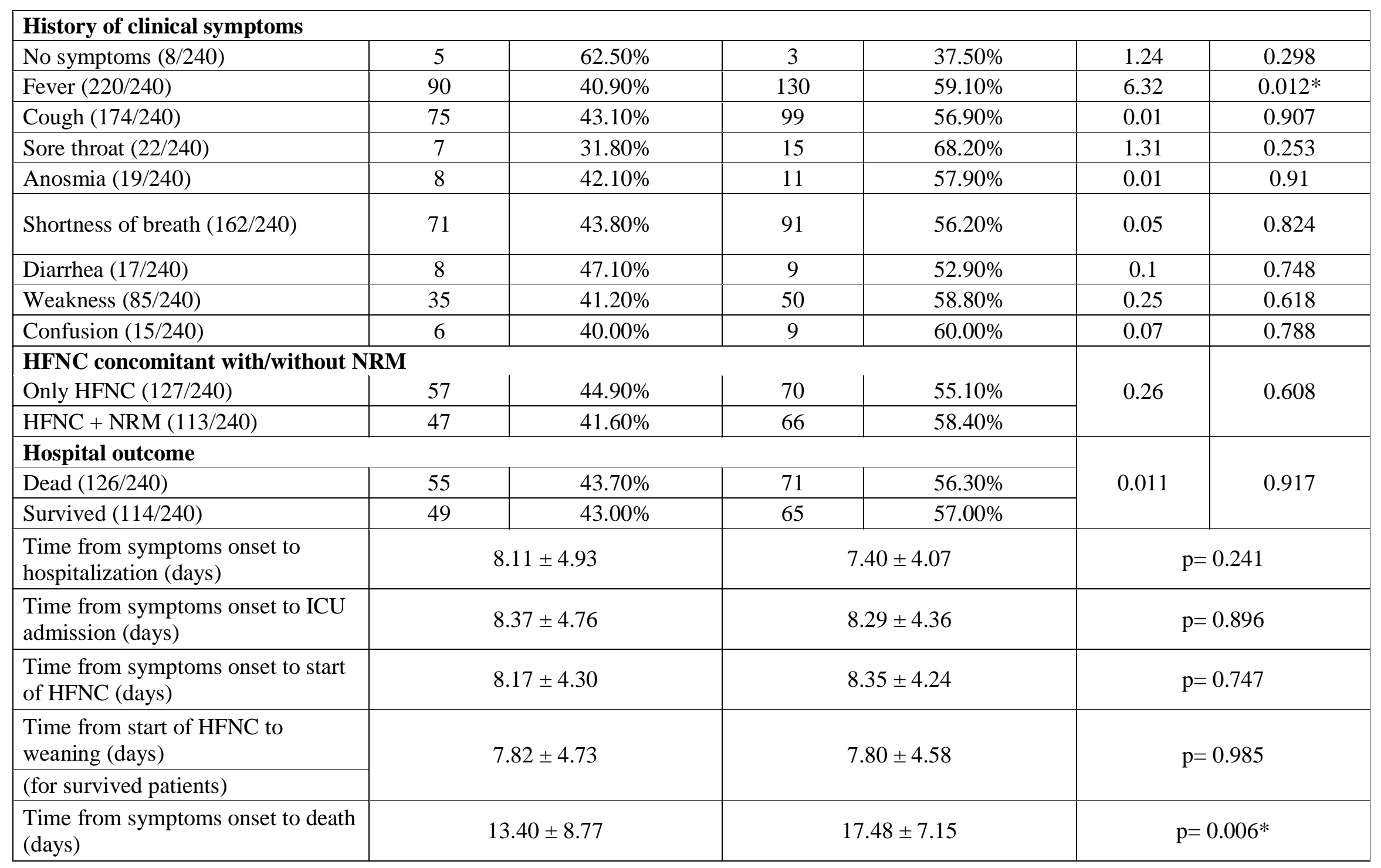




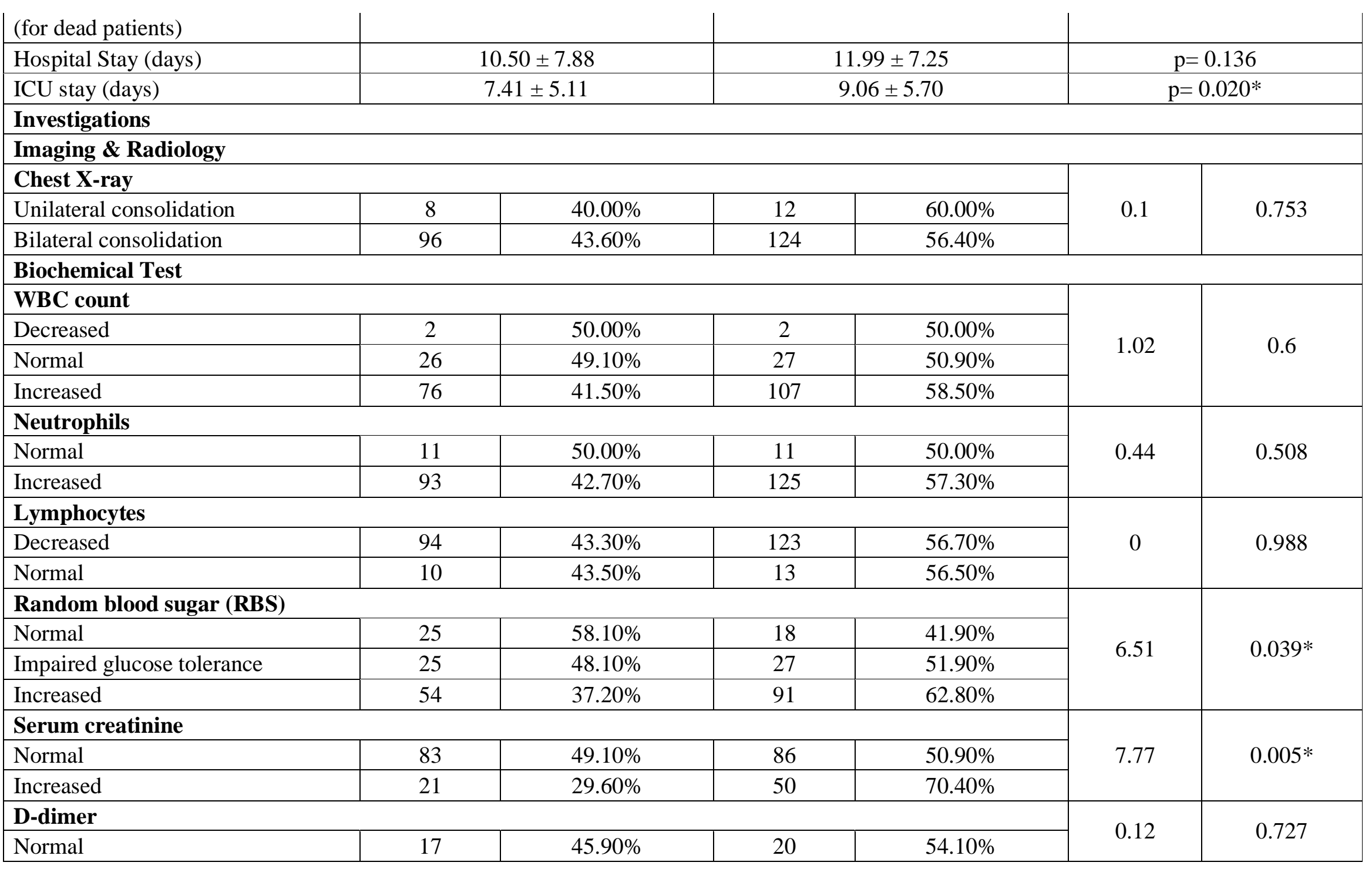




\begin{tabular}{|c|c|c|c|c|c|c|}
\hline Increased & 87 & $42.90 \%$ & 116 & $57.10 \%$ & & \\
\hline \multicolumn{5}{|l|}{ Serum Ferritin } & \multirow{3}{*}{0.77} & \multirow{3}{*}{0.381} \\
\hline Normal & 11 & $52.40 \%$ & 10 & $47.60 \%$ & & \\
\hline Increased & 93 & $42.50 \%$ & 126 & $57.50 \%$ & & \\
\hline No systemic inflammatory response & 80 & $44.20 \%$ & 101 & $55.80 \%$ & \multirow{3}{*}{2.32} & \multirow{3}{*}{0.509} \\
\hline $\begin{array}{l}\text { Moderate systemic inflammatory } \\
\text { response }\end{array}$ & 6 & $28.60 \%$ & 15 & $71.40 \%$ & & \\
\hline $\begin{array}{l}\text { Severe systemic inflammatory } \\
\text { response }\end{array}$ & 7 & $43.80 \%$ & 9 & $56.30 \%$ & & \\
\hline
\end{tabular}

Chi-Square Test, Fisher's Exact test, and Independent-Samples T-Test were used. $N=$ total number of patients. Row percentages were used, and significant P-values are marked with *. (HFNC= High Flow Nasal Cannula, NRM= Face mask with Non-rebreather Reservoir Bag, ICU= Intensive Care Unit, IHD= Ischemic Heart Disease, WBC= White Blood Cells) 
Table 2: Impact of HFNC (with/without NRM) for ICU admitted COVID-19 patients.

\begin{tabular}{|c|c|c|c|}
\hline Managements & $\begin{array}{l}\text { Non-diabetic } \\
(\text { Mean } \pm \text { SD) }\end{array}$ & $\begin{array}{c}\text { Diabetic } \\
(\text { Mean } \pm \text { SD })\end{array}$ & p-value \\
\hline Before starting HFNC- $\mathrm{SpO}_{2} \%$ & $82.47 \pm 8.11$ & $81.78 \pm 6.78$ & 0.484 \\
\hline \multicolumn{4}{|l|}{ On HFNC- average flow } \\
\hline Only HFNC & $57.98 \pm 10.22$ & $56.93 \pm 12.32$ & 0.599 \\
\hline HFNC + NRM & $56.30 \pm 11.02$ & $53.18 \pm 11.46$ & 0.149 \\
\hline \multicolumn{4}{|l|}{ After $\mathrm{HFNC}-\mathrm{SpO}_{2} \%$} \\
\hline Only HFNC & $90.53 \pm 6.03$ & $91.07 \pm 3.30$ & 0.542 \\
\hline HFNC + NRM & $89.98 \pm 5.16$ & $90.77 \pm 4.21$ & 0.387 \\
\hline \multicolumn{4}{|l|}{ On $\mathrm{HFNC}-\mathrm{FiO}_{2} \%$} \\
\hline Only HFNC & $81.39 \pm 15.66$ & $80.93 \pm 15.53$ & 0.870 \\
\hline $\mathrm{HFNC}+\mathrm{NRM}$ & $80.13 \pm 16.51$ & $79.53 \pm 14.85$ & 0.844 \\
\hline \multicolumn{4}{|l|}{ On $\mathrm{HFNC}-\mathrm{PaO}_{2}(\mathrm{mmHg})$} \\
\hline Only HFNC & $69.30 \pm 23.56$ & $61.50 \pm 14.49$ & $0.031 *$ \\
\hline HFNC + NRM & $59.40 \pm 13.22$ & $62.64 \pm 13.05$ & 0.201 \\
\hline \multicolumn{4}{|l|}{$\mathrm{P} / \mathrm{F}$ ratio $(\mathrm{mmHg})$} \\
\hline Only HFNC & $90.73 \pm 42.94$ & $81.08 \pm 32.95$ & 0.166 \\
\hline HFNC + NRM & $79.86 \pm 32.30$ & $82.76 \pm 27.22$ & 0.617 \\
\hline
\end{tabular}


Independent-Samples T-Test were used. Significant P-values are marked with *. (HFNC= High Flow Nasal Cannula, NRM= Face mask with Non-rebreather Reservoir Bag, ICU = Intensive Care Unit, AHRF= Acute Hypoxemic Respiratory Failure, SpO $O_{2}=$ Percent Saturation of Oxygen, $\mathrm{FiO}_{2}=$ Fraction of Inspired Oxygen, $\mathrm{PaO}_{2}=$ Partial Pressure of Oxygen, $\mathrm{SD}=$ Standard Deviation) 
Table 3: Impact of HFNC (with/without NRM) for ICU admitted COVID-19 (Diabetic/non-diabetic) patients.

\begin{tabular}{|c|c|c|c|c|c|c|c|c|}
\hline \multirow{3}{*}{ Variables } & \multicolumn{4}{|c|}{ Only HFNC } & \multicolumn{4}{|c|}{ HFNC + NRM } \\
\hline & \multicolumn{2}{|c|}{ Non-diabetic } & \multicolumn{2}{|c|}{ Diabetic } & \multicolumn{2}{|c|}{ Non-diabetic } & \multicolumn{2}{|c|}{ Diabetic } \\
\hline & Count & $\begin{array}{c}\text { Percent } \\
(\%)\end{array}$ & Count & $\begin{array}{c}\text { Percent } \\
(\%)\end{array}$ & Count & $\begin{array}{c}\text { Percent } \\
(\%)\end{array}$ & Count & $\begin{array}{c}\text { Percent } \\
(\%)\end{array}$ \\
\hline Age (years) & \multicolumn{4}{|c|}{$\mathrm{p}=0.035^{*}$} & \multicolumn{4}{|c|}{$\mathrm{p}<0.001 *$} \\
\hline Less than 50 & 21 & $60.0 \%$ & 14 & $40.0 \%$ & 17 & $81.0 \%$ & 4 & $19.0 \%$ \\
\hline \multirow[t]{2}{*}{50 and above } & 36 & $39.1 \%$ & 56 & $60.9 \%$ & 30 & $32.6 \%$ & 62 & $67.4 \%$ \\
\hline & \multicolumn{4}{|c|}{$\mathrm{p}<0.001^{*}$} & \multicolumn{4}{|c|}{$\mathrm{p}<0.001 *$} \\
\hline \multirow[t]{2}{*}{ No comorbidities } & 31 & $100.0 \%$ & 0 & $0.0 \%$ & 19 & $100.0 \%$ & 0 & $0.0 \%$ \\
\hline & \multicolumn{4}{|c|}{$\mathrm{p}<0.001 *$} & \multicolumn{4}{|c|}{$\mathrm{p}=0.008 *$} \\
\hline \multirow[t]{2}{*}{ Hypertension } & 20 & $29.9 \%$ & 47 & $70.1 \%$ & 26 & $33.3 \%$ & 52 & $66.7 \%$ \\
\hline & \multicolumn{4}{|c|}{$\mathrm{p}=0.068$} & \multicolumn{4}{|c|}{$\mathrm{p}=0.270$} \\
\hline \multirow[t]{2}{*}{ Ischemic heart disease } & 6 & $27.3 \%$ & 16 & $72.7 \%$ & 8 & $32.0 \%$ & 17 & $68.0 \%$ \\
\hline & \multicolumn{4}{|c|}{$\mathrm{p}=0.034^{*}$} & \multicolumn{4}{|c|}{$\mathrm{p}=0.200$} \\
\hline Fever & 47 & $41.6 \%$ & 66 & $58.4 \%$ & 43 & $40.2 \%$ & 64 & $59.8 \%$ \\
\hline Random blood sugar (RBS) & \multicolumn{4}{|c|}{$\mathrm{p}=0.206$} & \multicolumn{4}{|c|}{$\mathrm{p}=0.001 *$} \\
\hline Normal & 14 & $53.8 \%$ & 12 & $46.2 \%$ & 11 & $64.7 \%$ & 6 & $35.3 \%$ \\
\hline Impaired glucose tolerance & 6 & $28.6 \%$ & 15 & $71.4 \%$ & 19 & $61.3 \%$ & 12 & $38.7 \%$ \\
\hline
\end{tabular}




\begin{tabular}{|c|c|c|c|c|c|c|c|c|}
\hline Increased & 37 & $46.3 \%$ & 43 & $53.8 \%$ & 17 & $26.2 \%$ & 48 & $73.8 \%$ \\
\hline Serum creatinine & \multicolumn{4}{|c|}{$\mathrm{p}=0.189$} & \multicolumn{4}{|c|}{$\mathrm{p}=0.009^{*}$} \\
\hline Normal & 45 & $48.4 \%$ & 48 & $51.6 \%$ & 38 & $50.0 \%$ & 38 & $50.0 \%$ \\
\hline \multirow[t]{2}{*}{ Increased } & 12 & $35.3 \%$ & 22 & $64.7 \%$ & 9 & $24.3 \%$ & 28 & $75.7 \%$ \\
\hline & \multicolumn{4}{|c|}{$\mathrm{p}=0.065$} & \multicolumn{4}{|c|}{$\mathrm{p}=0.035^{*}$} \\
\hline \multirow{2}{*}{$\begin{array}{l}\text { Time from symptoms onset } \\
\text { to death (days) (for dead } \\
\text { patients) }\end{array}$} & \multicolumn{2}{|c|}{$13.45 \pm 10.81$} & \multicolumn{2}{|c|}{$17.64 \pm 7.06$} & \multicolumn{2}{|c|}{$13.33 \pm 5.30$} & \multicolumn{2}{|c|}{$17.22 \pm 7.42$} \\
\hline & \multicolumn{4}{|c|}{$\mathrm{p}=0.139$} & \multicolumn{4}{|c|}{$\mathrm{p}=0.070$} \\
\hline ICU stay (days) & \multicolumn{2}{|c|}{$7.63 \pm 5.09$} & \multicolumn{2}{|c|}{$9.06 \pm 5.57$} & \multicolumn{2}{|c|}{$7.15 \pm 5.18$} & \multicolumn{2}{|c|}{$9.06 \pm 5.87$} \\
\hline
\end{tabular}

Chi-Square Test, Fisher's Exact Test, and Independent-Samples T-Test were used. Row percentages were used, and significant P-values are marked with *. (HFNC= High Flow Nasal Cannula, NRM= Face mask with Non-rebreather Reservoir Bag, ICU= Intensive Care Unit, IHD= Ischemic Heart Disease, AHRF= Acute Hypoxemic Respiratory Failure, RBS= Random Blood Sugar) 
Table 4: Factors associated with HFNC only and HFNC+NRM management of ICU admitted diabetic COVID-19 patients.

\begin{tabular}{|c|c|c|c|c|}
\hline \multirow[b]{2}{*}{ Variables } & \multicolumn{2}{|c|}{ Only HFNC } & \multicolumn{2}{|c|}{$\mathrm{HFNC}+\mathrm{NRM}$} \\
\hline & COR with range $(95 \% \mathrm{CI})$ & AOR with range $(95 \% \mathrm{CI})$ & COR with range $(95 \% \mathrm{CI})$ & $\begin{array}{l}\text { AOR with range } \\
(95 \% \mathrm{CI})\end{array}$ \\
\hline \multicolumn{5}{|l|}{ Age (in years) } \\
\hline Less than 50 (ref) & 1.0 & 1.0 & 1.0 & 1.0 \\
\hline 50 and above & $2.3(1.1-5.2) *$ & $2.5(0.8-8.5)$ & $8.8(2.7-28.4) *$ & $5.8(1.1-31.2) *$ \\
\hline \multicolumn{5}{|l|}{ Comorbidity history } \\
\hline No comorbidities & $0.0(0.0)$ & $0.0(0.0)$ & $0.0(0.0)$ & $0.0(0.0)$ \\
\hline Hypertension & $3.8(1.8-7.9)$ & $0.7(0.2-2.2)$ & $3.0(1.3-6.8)^{*}$ & $0.1(0.01-0.8)^{*}$ \\
\hline \multicolumn{5}{|l|}{ Clinical sign } \\
\hline \multicolumn{4}{|l|}{ Random blood sugar } & $2.2(0.3-18.7)$ \\
\hline Normal (ref) & 1.0 & 1.0 & 1.0 & 1.0 \\
\hline Impaired glucose tolerance & $2.9(0.9-9.9)$ & $11.7(1.1-129.8)^{*}$ & $1.2(0.3-4.0)$ & $1.2(0.3-5.9)$ \\
\hline Increased & $1.4(0.6-3.3)$ & $1.5(0.4-5.0)$ & $5.2(1.7-16.2) *$ & $5.1(1.2-20.8)^{*}$ \\
\hline \multicolumn{5}{|l|}{ Serum creatinine } \\
\hline Normal (ref) & 1.0 & 1.0 & 1.0 & 1.0 \\
\hline Increased & $0.6(0.3-1.3)$ & $0.6(0.2-1.8)$ & $3.1(1.3-7.5) *$ & $2.1(0.7-6.3)$ \\
\hline
\end{tabular}

Simple and Multiple Bivariate logistic regression was used and p-values less 0.05 (marked with * and are bold) are considered significant. (COR= Crude Odds Ratio, AOR= Adjusted Odds Ratio.)

**Times from symptoms onset to death is removed from the analysis as it is strongly correlated with other factors. 
medRxiv preprint doi: https://doi.org/10.1101/2021.10.13.21264946; this version posted December 13, 2021. The copyright holder for this preprint (which was not certified by peer review) is the author/funder, who has granted medRxiv a license to display the preprint in perpetuity.

All rights reserved. No reuse allowed without permission.

Supplementary Figure 1: Immediate complications of (a) diabetic and (b) non-diabetic patients, accordingly. $\mathrm{X}$ and $\mathrm{Y}$ axis indicate different complications and \% of patients, respectively. Blue and red shades individually signify death and survival rates of the patients having faced the particular complication. $\mathrm{N}=$ total number of patients suffered from the specific complication. 